\title{
The control of radioactive pollution in a North Sea oyster fishery
}

\author{
Alan Preston \\ Ministry of Agriculture, Fisheries and Food, Fisheries Radiobiological Laboratory, \\ Hamilton Dock, Lowestoft, Suffolk, England
}

KURZFASSUNG: Die Kontrolle radioaktiver Verunreinigung in einer Austernfischerei der Nordsee. Im Ästuar des Flusses Blackwater wird eine kommerzielle Austernfischerei betrieben. In die Flußmündung werden in niedrigen Konzentrationen radioaktive $A b w a ̈ s s e r$ von der Bradwell Nuclear Power Station geleitet. Die Situation bezüglich der radioaktiven Verunreinigung des Flusses wird dargestellt und das Uberwachungssystem des Ministry of Agriculture, Fisheries and Food beschrieben, wobei darauf hingewiesen wird, daß die Stärke der Radioaktivität auf einer kommerziell genutzten Austernbank ausreichend gut kontrolliert werden kann. Das kritische Radionuklid ist ${ }^{6} \mathrm{Zn}$, das im Austernfleisch enthalten ist. Anhand der Werte der spezifischen Aktivität von ${ }^{65} \mathrm{Zn},{ }^{60} \mathrm{Co},{ }^{55} \mathrm{Fe}$ und ${ }^{137} \mathrm{Cs}$ von Austern, die in unmittelbarer $N a$ he des $A b$ wassereinflusses lebten, wird gezeigt, daß im ungünstigsten Falle der Austernkonsument $0,2 \%$ der von der I.C.R.P. zugelassenen Menge aufnimmt.

\section{INTRODUCTION}

This paper describes the methods employed by the Ministry of Agriculture, Fisheries and Food (M.A.F.F.) in controlling radioactive pollution in the River Blackwater oyster fishery. The majority of radioactive contaminants are introduced to the estuary through the discharge of low-level aqueous radioactive effluent from the Central Electricity Generating Board's nuclear power station at Bradwell-on-Sea, Essex.

The methods of pre-operational assessment employed at power station sites for the discharge of such radioactive wastes have already been discussed in general terms (Preston 1966a) and in detail in relation to Bradwell (Preston 1966b), and only a summary of the essential results of this part of the work will be presented.

The main body of data reported refer to the results of the first four years of work in relation to the monitoring of oysters in the estuary with particular respect to zinc65 , but some data on other magnox corrosion products such as cobalt- 60 and iron- 55 , and the fission product caesium-137, are also presented. 


\section{THE BLACKWATER SITUATION}

Aqueous radioactive effluent from the Bradwell power station arises principally from the fuel element cooling ponds. The major radionuclides in the effluent are produced by neutron activation of constituents in the magnox fuel-cladding used for the fuel element assemblies in the station's reactors. The spent fuel is withdrawn from the reactor and submerged in ponds at high $\mathrm{pH}$ for a period of approximately 100 days to allow the short-lived isotopes to decay. During this time corrosion takes place, and activation products and some fission products enter the pond water. The radioactive content of this pond water is kept to acceptable operational levels by continuously passing a small volume of the water through ion-exchange beds; and the bulk of the ${ }^{65} \mathrm{Zn}$ activity can, if desired, be removed on a non-regenerable resin. The back washings of the other regenerable resins are the principal source of the corrosion product activity discharged to the estuary. A typical composition for the principal nuclides in this type of effluent is given in Table 1, based on the results of M.A.F.F. analyses of monthly bulk samples of discharge obtained from the Bradwell power station during the twelve months ending April 1967.

The metal activation products are divisible into groups: ${ }^{85} \mathrm{Zn},{ }^{60} \mathrm{Co},{ }^{55} \mathrm{Fe}$ and ${ }^{54} \mathrm{Mn}$, which have a substantial particulate fraction; ${ }^{124} \mathrm{Sb}$ and ${ }^{125} \mathrm{Sb}$, which are largely soluble; and ${ }^{51} \mathrm{Cr}$, which occupies an intermediate position, the size of its particulate fraction being highly variable (19 to $88 \%$ ). It is the isotopes of the first group, particularly zinc, which are highly concentrated by shellfish, and which, together with the fission product ${ }^{137} \mathrm{Cs}$, have been identified in the Blackwater environment and especially in oysters.

The critical situation setting the maximum permissible rate of discharge for aqueous radioactive effluent at the site is the consumption of oyster flesh by the local population. The critical radionuclide, by virtue of its high concentration factor in oyster flesh $\left(10^{5}\right.$ in this environment), is ${ }^{65} \mathrm{Zn}$, and its rate of discharge is especially restricted. The major steps in deriving a permissible discharge rate for this radionuclide, based on the permissible daily intake for members of the public derived from I.C.R.P. recommendations (I.C.R.P. 1963), are set out in Table 2.

Table 2

Provisional estimate of the maximum permissible discharge rate of zinc-65 to the Blackwater Estuary Estimated concentration of ${ }^{B 5} \mathrm{Zn}$ in estuary per curie released per day
$(\mu \mathrm{Ci} / \mathrm{ml})$

$1.5 \times 10^{-7}$

$10^{5}$

Concentration factor in oyster flesh

1.1

Daily intake of ${ }^{65} \mathrm{Zn}$ in $75 \mathrm{~g}$ of oyster flesh $(\mu \mathrm{Ci})$

$2.2 \times 10^{-1}$

I.C.R.P. maximum permissible daily intake $(\mu \mathrm{Ci})$

0.2

Estimated maximum permissible daily discharge rate of ${ }^{65} \mathrm{Zn}$ (Ci) 


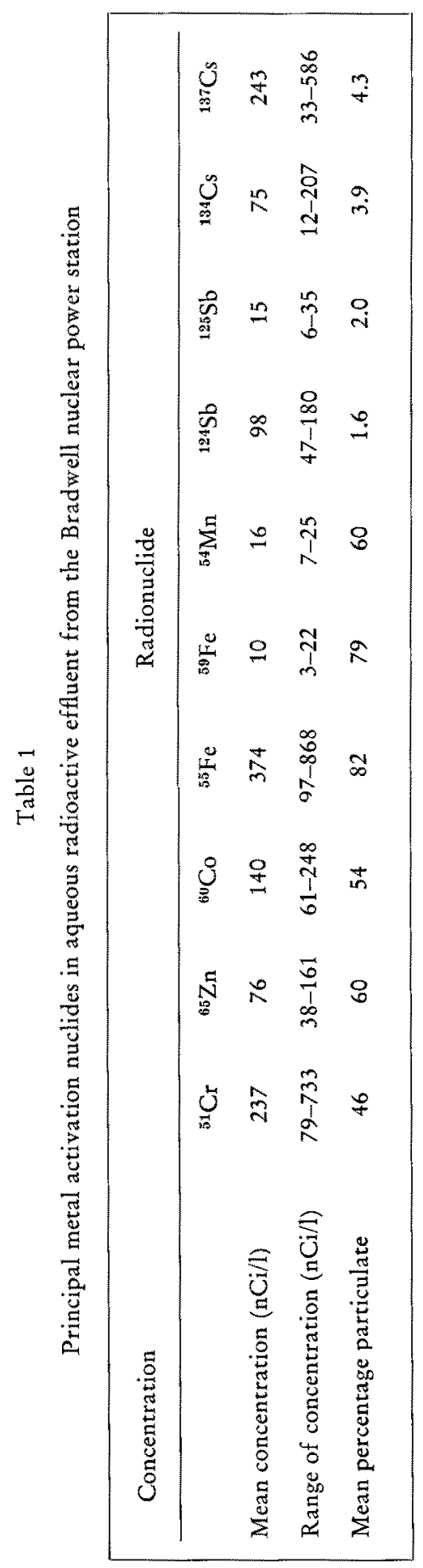




\section{THE OYSTER MONITORING SCHEME IN THE BLACKWATER}

The locations of the oyster sampling positions for a full-scale survey are indicated in Figure 1. The nucleus of the oyster sampling programme, as operated prior to, and during the early phase of, effluent discharge, was confined to a few positions on the southern shore and was arranged so as to provide data on which to assess the maximum

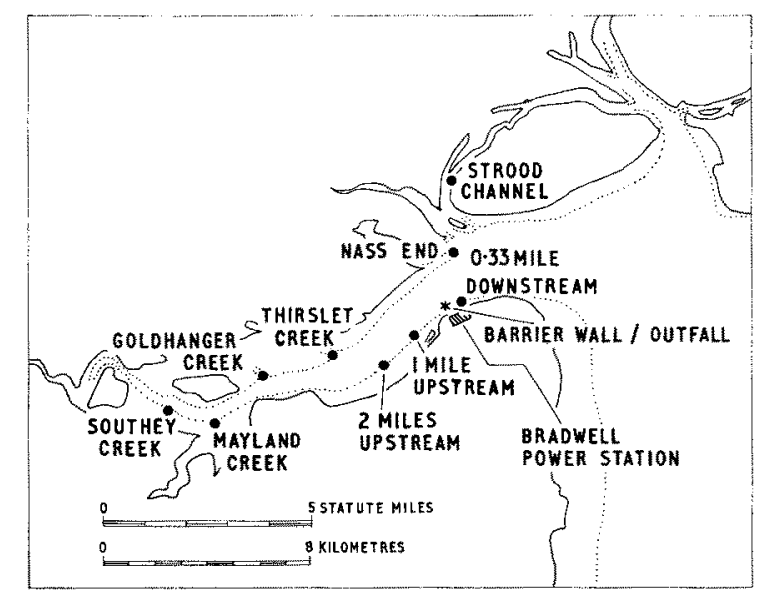

Fig. 1: M.A.F.F. sampling positions for oysters in the Blackwater Estuary

permissible rate of discharge of ${ }^{65} \mathrm{Zn}$. This early programme included special layings of oysters in trays at the cooling water outfall, to provide the earliest possible warning of radioactive contamination of oyster flesh. Other positions were established at commercial beds to show the build-up of ${ }^{65} \mathrm{Zn}$ and other radionuclides in oysters throughout the estuary. This system permits the concentrations in oysters at the various sampling points to be related to distance from the outfall and so provides a basis for estimating concentrations at other oyster beds within the estuary.

\section{THE DISTRIBUTION OF ${ }^{\circ} \mathrm{Zn}$ IN OYSTERS IN THE ESTUARY}

\section{Distribution in the estuary as a whole}

Oysters have been sampled monthly since 1963 at a number of the positions indicated in Figure 1. These positions were at first concentrated on the southern shore, with one indicator station across the estuary from the power station cooling water outfall. They were later extended for the twelve months ending March 1967, to include monthly sampling points on the northern shore, thus providing a complete picture of the distribution of ${ }^{65} \mathrm{Zn}$ in oysters throughout the estuary. The average concentrations of ${ }^{\circ 5} \mathrm{Zn}$ in oysters at all positions throughout this twelve, month period are shown in 
Figure 2, where the values have been normalized to 100 at the cooling water outfall (40.6 pCi/g wet weight of oyster flesh).

The data show that the distribution of ${ }^{65} \mathrm{Zn}$ in oysters is markedly biased towards the southern shore, particularly near the mouth of the estuary. This is consistent with the ${ }^{65} \mathrm{Zn}$ activity being associated with silt so that it is pushed along the estuary in the

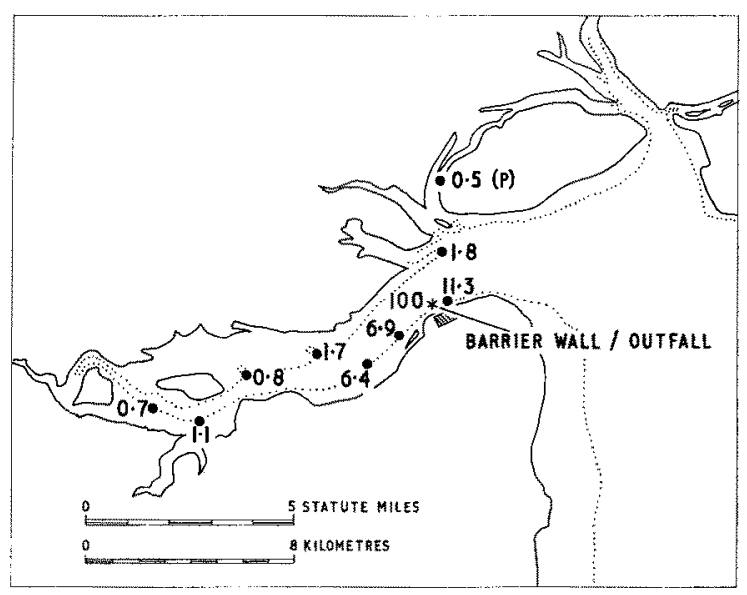

Fig. 2: Zinc-65 in native oyster flesh normalized to 100 at the cooling water outfall ( $\mathrm{pCi} / \mathrm{g}$ wet). P - Portuguese oysters

direction of the main tidal streams, i.e. longitudinally not transversely. If the zinc were in ionic form it would be distributed in a manner more consistent with the movement of the main water masses, but since hydrographical observations indicate mixing to be very good and virtually complete in the wide mouth of the estuary (TALBOT 1967), the zinc is clearly not mixing in a manner consistent with this interpretation. Evidence in support of the silt-borne hypothesis is afforded by experimental work with ${ }^{65} \mathrm{Zn}$ adsorbed on illite in sea-water (CHESTER 1965), where $90 \%$ of the activity was adsorbed on to the illite particles in 40 hours. At present, the rates of discharge of ${ }^{65} \mathrm{Zn}$ are too low to permit its measurement in water or on silt, so that the testing of this explanation is not possible. However, studies made on stable zinc in the estuary (HAMPSON 1966) indicate that about $15 \%$ is ionic and $85 \%$ is particulate, in colloidal form or associated with organic complexes, so that the distribution of stable zinc also supports the ${ }^{65} \mathrm{Zn}$-silt hypothesis.

\section{Distribution on the southern shore}

The results from the southern shore stations between November 1964 and June 1967 are illustrated in Figure 3, where the concentration of ${ }^{65} \mathrm{Zn}$ in oyster flesh at any position between 0.33 and 5.75 miles from the station outfall can be represented by:

$\mathrm{C}\left({ }^{65} \mathrm{Zn} \mathrm{pCi} / \mathrm{g}\right.$ wet $)=2.16 \times \mathrm{D}(\text { distance in statute miles from outfall })^{-0.78}$. 
The ${ }^{65} \mathrm{Zn}$ concentrations for the oysters at the cooling water outfall are lower than could be expected from extrapolation of the results between 0.33 and 5.75 miles, or, alternatively, the rate of decrease of ${ }^{65} \mathrm{Zn}$ concentration over the first 0.33 miles is less than that thereatter. This is probably consistent with the time (distance) required

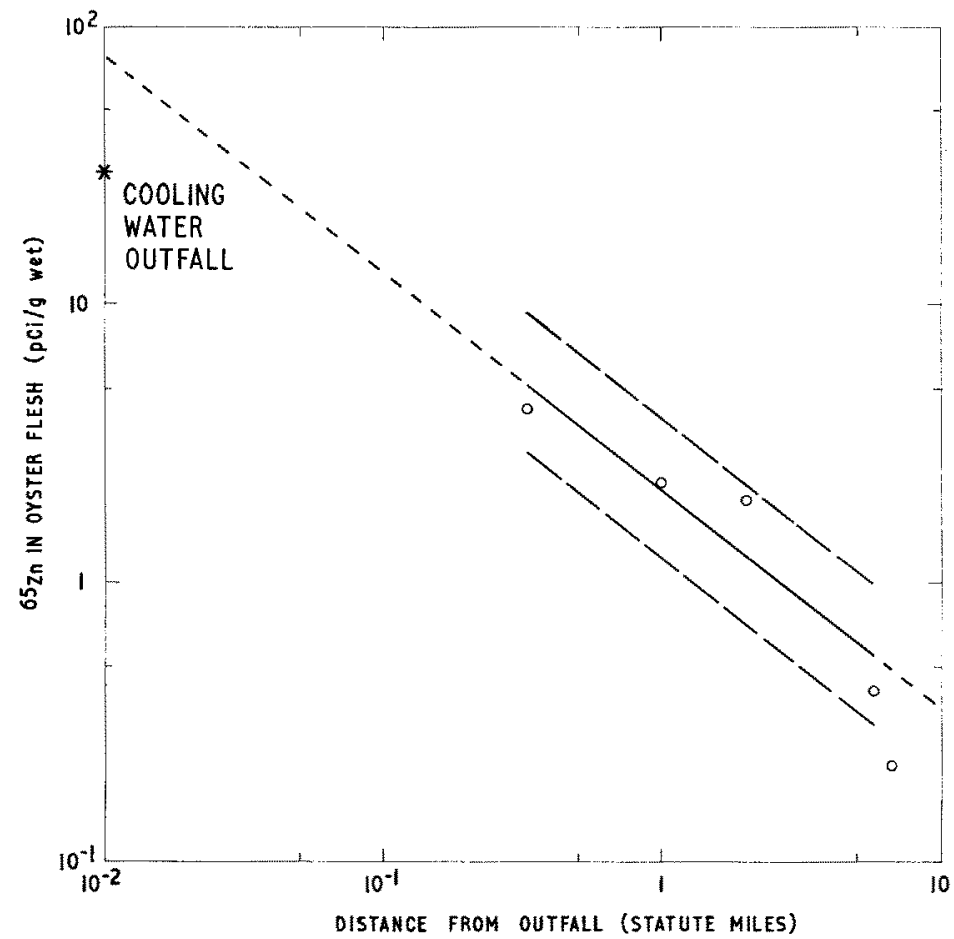

Fig. 3: The relationship between the concentration of zinc-65 in oyster flesh and distance from the Bradwell cooling water outfall, for the period November 1964 to June 1967

to establish the adsorption of $65 \mathrm{Zn}$ on silt and a regular pattern of silt movement and dilution. The sharp discontinuity which occurs in the graph between 5.75 and 6.75 miles corresponds with the boundary of the average tidal excursion (TALBOT 1967), this distal sampling position being outside the initial mixing volume defined by an average tidal excursion centred on the outfall.

Distribution at the commercial bed nearest to the outfall

The data presented in Figure 4 illustrate the build-up of ${ }^{65} \mathrm{Zn}$ activity in the flesh of native oysters at the commercial bed nearest to the station outfall, 0.33 miles away. The pattern of ${ }^{65} \mathrm{Zn}$ discharged is also illustrated, and the relatively smooth rate of increase of concentration in oyster flesh in relation to the rate of discharge is appa- 
rent. These data suggest that unless there are major changes in the rate and pattern of discharges the oysters are now near equilibrium.

The activities due to ${ }^{55} \mathrm{Zn}$ in the constituent parts of native oysters are given in Table 3 , both as a concentration, and as a total of activity in each portion, relative to

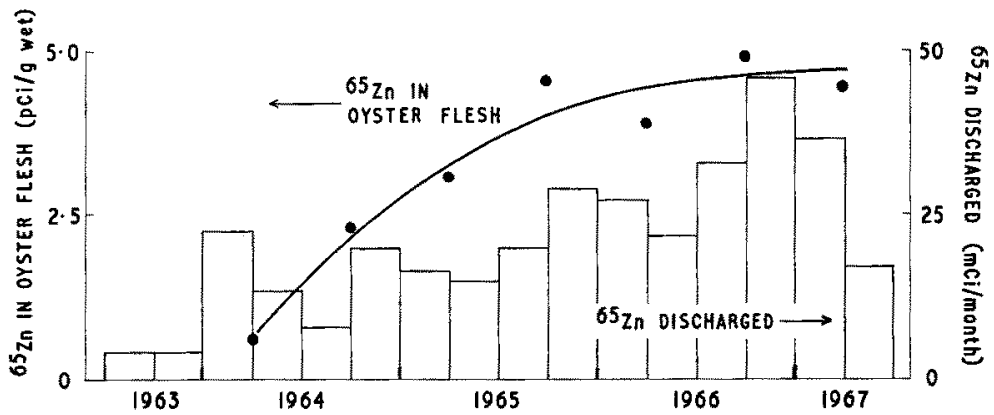

Fig. 4: The concentration of zinc- 65 in oyster flesh at the commercial bed 0.33 miles from the cooling water outfall, and the quantity of zinc- 65 discharged from the outfall

Table 3

The concentration of zinc-65 in native oysters at the commercial bed nearest to the outfall: mean of twelve observations October 1965 to September 1966, relative to 100 for the maximum

\begin{tabular}{|lcc|}
\hline \multirow{2}{*}{ Organs } & \multicolumn{2}{c|}{ Concentration of ${ }^{65} \mathrm{Zn}$} \\
& pCi/g wet & pCi per organ \\
\hline Mantle & 64 & 20 \\
Gills & 100 & 48 \\
Muscle & 20 & 10 \\
Rest & 59 & 100 \\
\hline
\end{tabular}

100 for the maximum. Muscle has the lowest concentration and contributes the smallest quantity of activity to the oyster consumer. As might be expected, the highest concentration of activity is associated with the gills, these being the original site of deposition of silt particles carrying the nuclide.

\section{OTHER RADIONUCLIDES}

The radionuclide ${ }^{60} \mathrm{Co}$ has been identified and measured in oysters taken from the southern shore at 0 to 5.75 miles from the outfall. The concentrations are quite low and it was necessary to separate chemically and electroplate the cobalt in order to measure it accurately (DutTon et al. in preparation). In Figure 5 the results for the southern positions for the twelve months ending March 1967 are displayed as an average concentration against distance, and it appears that ${ }^{60} \mathrm{Co}$ activity is very similar to ${ }^{65} \mathrm{Zn}$ in this respect, the slopes of the concentration distance lines between 0.33 and 5.75 miles being identical at -0.77 for the same period of time. 
A few results available for ${ }^{137} \mathrm{Cs}$ from July to December 1965 are also shown in Figure 5. This fission-product radionuclide appears in the effluent from time to time, following the perforation of fuel elements in the pond. The concentrations in oysters indicate a much more uniform distribution of this radionuclide in the estuary than

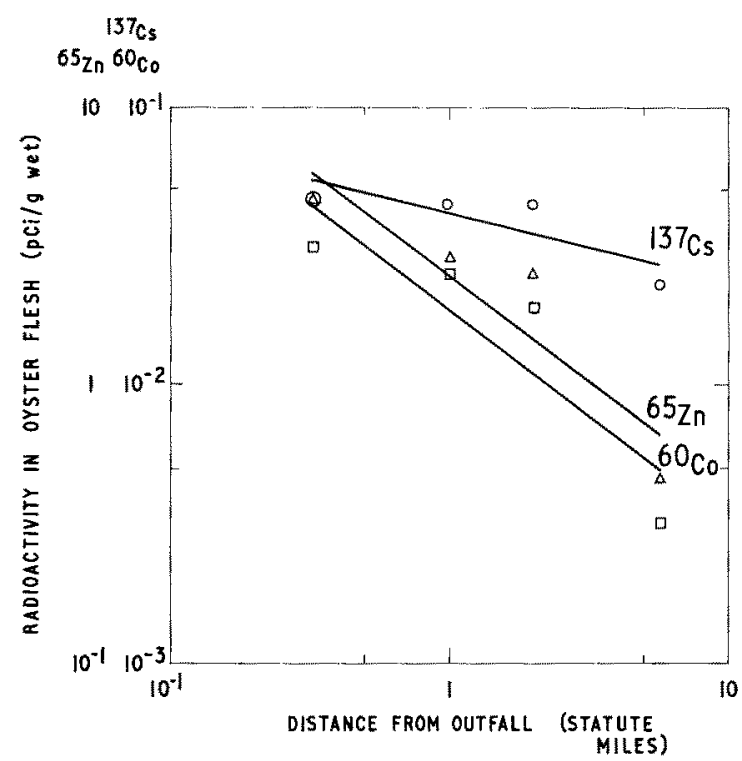

Fig. 5: The relationship between the concentration of radioactivity in oyster flesh and distance from the Bradwell cooling water outfall. ${ }^{137} \mathrm{Cs}$ - July-December $1965,{ }^{65} \mathrm{Zn}$ - April 1966 March 1967, ${ }^{60} \mathrm{Co}-$ April 1966-March 1967

Table 4

The concentrations of iron-55, zinc- 65 , cobalt -60 and caesium-137 in oysters at the barrier wall layings and 0.33 miles from the barrier wall, the nearest commercial bed

\begin{tabular}{|c|c|c|c|}
\hline \multirow{2}{*}{ Isotopes } & \multicolumn{2}{|c|}{ Concentration ( $\mathrm{pCi} / \mathrm{g}$ wet) } & \multirow{2}{*}{$\frac{\text { Barrier wall }}{0.33 \text { miles }}$} \\
\hline & Barrier wall & 0.33 miles & \\
\hline${ }^{55} \mathrm{Fe}$ & 0.79 & 0.067 & 12 \\
\hline${ }^{85} \mathrm{Zn}$ & 43.1 & 4.44 & 9.7 \\
\hline${ }^{60} \mathrm{Co}$ & 0.35 & 0.031 & 12 \\
\hline${ }^{137} \mathrm{Cs}$ & 0.17 & 0.047 & 3.6 \\
\hline
\end{tabular}

is exhibited by either ${ }^{60} \mathrm{Co}$ or ${ }^{65} \mathrm{Zn}$ (the slope of the concentration distance line is -0.23 ), and this is as would be expected from the known behaviour of ${ }^{137} \mathrm{Cs}$ in the marine environment at Windscale.

Finally, there are also some data available for ${ }^{55} \mathrm{Fe}$ in oysters from the barrier wall layings and from the nearest commercial bed. These are given in Table 4, where 
the ratio of the concentrations for this nuclide for the two positions is compared with those for ${ }^{65} \mathrm{Zn}$, ${ }^{60} \mathrm{Co}$ and ${ }^{137} \mathrm{Cs}$. The ratios suggest that ${ }^{55} \mathrm{Fe}$, like ${ }^{65} \mathrm{Zn}$ and ${ }^{60} \mathrm{Co}$, is rapidly adsorbed on to silt and that its distribution is therefore rather sharply restricted compared with that of ${ }^{137} \mathrm{Cs}$.

Table 5

The percentage of the I.C.R.P. recommended Dose Limit for individual members of the general public received by consumers eating $75 \mathrm{~g} /$ day of oysters from the commercial bed nearest to the outfall

\begin{tabular}{|c|c|c|c|}
\hline \multirow{2}{*}{ Isotopes } & \multicolumn{3}{|c|}{ Percentage of maximum permissible dose-rate } \\
\hline & Bone & Gastro-intestinal Tract & Total Body \\
\hline${ }^{55} \mathrm{Fe}$ & $<0.001$ & $<0.001$ & $<0.001$ \\
\hline${ }^{85} \mathrm{Zn}$ & 0.016 & 0.079 & 0.158 \\
\hline${ }^{60} \mathrm{Co}$ & - & 0.002 & 0.001 \\
\hline${ }^{137} \mathrm{Cs}$ & 0.003 & $<0.001$ & 0.008 \\
\hline Total & 0.020 & 0.083 & 0.168 \\
\hline
\end{tabular}

\section{THE RADIOLOGICAL STATUS OF THE BLACKWATER OYSTER FISHERY}

The data on ${ }^{65} \mathrm{Zn}$ and ${ }^{60} \mathrm{Co}$ in effluent, and in oysters on the southern shore, may be used to derive maximum permissible discharge rates for these two radionuclides. The maximum rate of consumption of oysters from within the estuary has been established by local survey to be $75 \mathrm{~g}$ per day. The limitation set by this rate of consumption from any commercial bed within the range 0.33 to 5.75 miles from the outfall may be determined from the concentration-distance relationship for a unit rate of discharge:

$\left.\begin{array}{l}\mathrm{C}\left({ }^{65} \mathrm{Zn}\right)=0.083 \times \mathrm{D}^{-0.77} \\ \mathrm{C}\left({ }^{60} \mathrm{Co}\right)=0.00031 \times \mathrm{D}^{-0.77}\end{array}\right\}$ per millicurie discharged per month.

If the distance (D) of an oyster bed from the outfall is known and the concentration (C) is set equal to the derived concentration based on I.C R.P's recommended Dose Limit, the derived permissible daily intake and the observed $75 \mathrm{~g}$ per day consumption rate $\left(2900 \mathrm{pCi} / \mathrm{g}^{65} \mathrm{Zn} ; 1500 \mathrm{pCi} / \mathrm{g}^{60} \mathrm{Co}\right)$, a permissible discharge rate can be calculated taking account of the consumption of oysters from that particular bed. Reference to Figure 2 shows that a discharge rate based on such a calculation for the oyster bed 0.33 miles from the outfall would ensure the acceptability of oysters from anywhere in the estuary. By using the most recent data for the critical radionuclide ${ }^{65} \mathrm{Zn}$ for oysters from this bed, the maximum permissible discharge rate is found to be $0.66 \mathrm{Ci}$ per day, which is within a factor of 3 of the original estimate (Table 2).

The present concentrations of ${ }^{65} \mathrm{Zn},{ }^{60} \mathrm{Co},{ }^{55} \mathrm{Fe}$ and ${ }^{137} \mathrm{Cs}$ in oysters at the commercial bed nearest to the outfall can also be used to make estimates of the organ dose-rates experienced by exceptional oyster consumers, by comparing the daily intake from oysters with the daily intake derived from I.C.R.P. recommendations. This is 
done in Table 5 for the three organs Bone, Gastro-intestinal Tract and Total Body, on the pessimistic assumption that all the radioactivity is soluble. It is immediately apparent that only a very small fraction of the continuous permissible daily exposure rate would be experienced by even the most exceptional oyster consumer if his entire consumption was met from this particular bed. It is also clear that the Total Body is receiving the largest fraction of the recommended Dose Limit and is therefore the critical organ.

\section{SUMMARY}

1. The radiological situation in the Blackwater estuary is reviewed.

2. Some data are produced to contrast the behaviour of particulate and soluble nuclides in this estuarine environment and it is demonstrated that ${ }^{65} \mathrm{Zn}$, ${ }^{60} \mathrm{Co}$ and ${ }^{55} \mathrm{Fe}$ probably reach the oysters on fine silt particles.

3. The conclusion of the pre-operational assessment is confirmed, that oysters are the critical material and ${ }^{65} \mathrm{Zn}$ is the critical radionuclide.

4. At present, oysters are the only material in which measurable concentrations of activity exist throughout the estuary.

5. The maximum dose-rates experienced by exceptional oyster consumers are less than $0.2 \%$ of the I.C.R.P. permissible Dose Limits for members of the public.

6. A system is developed to relate oyster contamination, and consequently discharge rate of radioactivity, to any distance from the power station outfall.

A cknow ledgements: Grateful acknowledgement is paid to my various colleagues for assistance with sample collection, radiochemical and numerical analysis and preparation of tables and figures, but especially to Mr. D. F. JeFreries and Mr. B. H. MACE.

\section{LITERATURE CITED}

Chester, R., 1965. Adsorption of zinc and cobalt on illite in seawater. Nature, Lond. 206 (4987), 884-886.

Dutton, J. W. R., Harvex, B. R. \& Robson, J. C., 1967. Technical report (to be published by Ministry of Agriculture, Fisheries and Food, Lowestoft).

Hampson, B. L., 1966. Unpublished data.

International Commission on Radtologtcal Protection, 1963. Report of Committee II on permissible dose for internal radiation, 1959. In: I.C.R.P. Publication 2. Pergamon Press, Oxford.

Preston, A., 1966a. Site evaluations and the discharge of radioactive wastes from civil nuclear power stations in England and Wales. In: Disposal of radioactive wastes into seas, oceans and surface waters. I.A.E.A. Symposium held in Vienna, Austria, 16-20 May 1966. Internationale Atom-Energie-Organisation, Wien, 725-737.

- 1966b. The concentration of zinc-65 in the flesh of oysters related to the discharge of cooling pond effluent from the C.E.G.B. nuclear power station at Bradwell-on-Sea, Essex. In: Radioecological concentration processes. Proceedings of a symposium held in Stockholm. Ed. by B. Åborg \& F. P. Hungate. Pergamon Press, Oxford, 995-1004.

TALBoT, J. W., 1967. The hydrography of the estuary of the River Blackwater. Fishery Invest., Lond. (Ser. 2) 25 (6) $92 \mathrm{pp.}$ 


\section{Discussion following the paper by PRESTON}

HaNnerz: Have you been able to find zinc in bottom sediments, and if so, has this any importance to sea bathing?

JefFERIES: ${ }^{65} \mathrm{Zn}$ has been detected in silt near the outfall but at a very low level, probably less than $0.005 \mathrm{x}^{65} \mathrm{Zn}$ in oyster flesh at the outfall. At such low levels there is no problem as to sea bathing anywhere in the estuary.

HANNERZ: Have you any idea as to the way of uptake of ${ }^{65} \mathrm{Zn}$ in oysters? Is it mainly from the water or by the food?

JEFFERIES: ${ }^{65} \mathrm{Zn}$ appears to be associated with silt and, as the paper shows, the highest concentration of activity is associated with the gills. This suggests uptake of ${ }^{65} \mathrm{Zn}$ is from silt via the gills.

Lievens: I should like to have the following complementary information: (1) Which are the characteristics of the Bradwell nuclear reactor or reactors: cooling system, moderating element, power level? (2) Which are the hydrographical characteristics on the place of discharging? (3) Are there other materials discharged as cooling water?

Jefferres: The Bradwell reactors are of the Calder Hall type, i. e. the fuel is natural uranium, carbon dioxide cooled, graphite moderated. The fuel elements are uranium rods, sheathed in magnesium alloy. The condenser cooling water flow is about 20 million gallons per hour. The contents of active effluent delay tanks are injected into the cooling water flow from time to time and are thus discharged at the outfall. Hydrographical details of the estuary will be given by J. W. Tацвот, of the Fisheries Laboratory in Fishery Invest., Lond. (Ser. 2) 25 (6), 92 pp. In answer to the third question, some tritium waste is discharged but tritium is of low radiotoxicity. The condenser cooling water is also chlorinated.

Feldt: Bei der Berechnung der maximalen Ablaßrate für Zn-65 wurde die Empfehlung der IGRP hinsichtlich der zulässigen maximalen täglichen Zufuhr von Zn-65 sowie der Austernverbrauch berücksichtigr. Dieses Verfahren ist nur anwendbar, wenn nur $\mathrm{Zn}-65$ entlassen wird und nur die Austern kontaminiert werden. Sind bei der angegebenen Zahl sowohl die anderen Radionuklide berïcksichtigt worden als auch das gesamte Nahrungsspektrum als Träger für die Zufuhr radioaktiver Nuklide? Aus Ihrer Darstellung konnte ich es nicht klar erkennen.

JEFFERIES: The provisional estimate of maximum permissible discharge rates takes into account all radionuclides in the expected effluent composition. Similar calculations are made as those for Zinc-65. Knowing the relative proportion of each radionuclide, in a typical effluent, it is possible to calculate a maximum permissible discharge rate of gross radioactivity. At Bradwell, because of the reconcentration factor of $10^{5}$ for ${ }^{65} \mathrm{Zn}$ by oysters, it is necessary to restrict this particular radionuclide. The authorisation to discharge includes both total Beta radioactivity and ${ }^{65} \mathrm{Zn}$.

KorRINGA: Zinc can be the limiting factor in deciding permissible quantities of radioactive waste to be discharged. Therefore much attention has been paid to zinc, in the EuratomCNEN laboratory at Fiascherino, Italy. Chelating agents make it possible to take away a high percentage of the zinc from the waste of nuclear plants, thus making it possible to increase the volume of radiation water to be discharged. 